\title{
Tumoral Calcinosis During the Course of Systemic Sclerosis
}

ALEXANDRA AUDEMARD, MD; NICOLAS MARTIN SILVA, MD; JONATHAN BOUTEMY, MD; GWENOLA MAIGNÉ, MD; BORIS BIENVENU, MD, PhD, Department of Internal Medicine, Caen University Hospital, and the Faculty of Medicine, University Caen, Caen, France. Address correspondence to Dr. A. Audemard, Department of Internal Medicine, CHU Côte de Nacre, BP 95182, 14033 Caen cedex 9, France.

E-mail: alexandra.audemard@hotmail.fr. J Rheumatol 2015;42:348; doi:10.3899/jrheum.140335

Although rare, tumoral calcinosis can occur during the course of systemic sclerosis (SSc).

A 51-year-old woman was diagnosed in 2011 with limited cutaneous SSc, complicated by myositis. The main clinical manifestation was extensive calcinosis at multiple localizations (hip, finger, back, neck), leading to significantly reduced quality of life. One year later, she complained of left coxalgia. Computed tomography demonstrated tumoral soft tissue calcification surrounding the left hip joint (Figure 1). Ectopic soft tissue calcinosis is frequent (i.e., 25\%) in limited SSc. Lesions are commonly located in pressure areas, most frequently in the hands. Calcinosis presumably occurs in tissues damaged by mechanical stress, hypovascularity, and tissue hypoxia ${ }^{1}$. Tumoral calcinosis can occur during the course of SSc, but is very rare. Treatments with warfarin, colchicine, bisphosphonate, diltiazem, minocycline, and surgical excision have been reported, but none have shown significant efficacy ${ }^{1,2,3}$.

\section{REFERENCES}

1. Boulman N, Slobodin G, Rozenbaum M, Rosner I. Calcinosis in rheumatic diseases. Semin Arthritis Rheum 2005;34:805-12.

2. Sultan-Bichat N, Menard J, Perceau G, Staerman F, Bernard P, Reguiaï Z. Treatment of calcinosis cutis by extracorporeal shock-wave lithotripsy. J Am Acad Dermatol 2012;66:424-9.

3. Saddic N, Miller JJ, Miller OF 3rd, Clarke JT. Surgical debridement of painful fingertip calcinosis cutis in CREST syndrome. Arch Dermatol 2009;145:212-3.

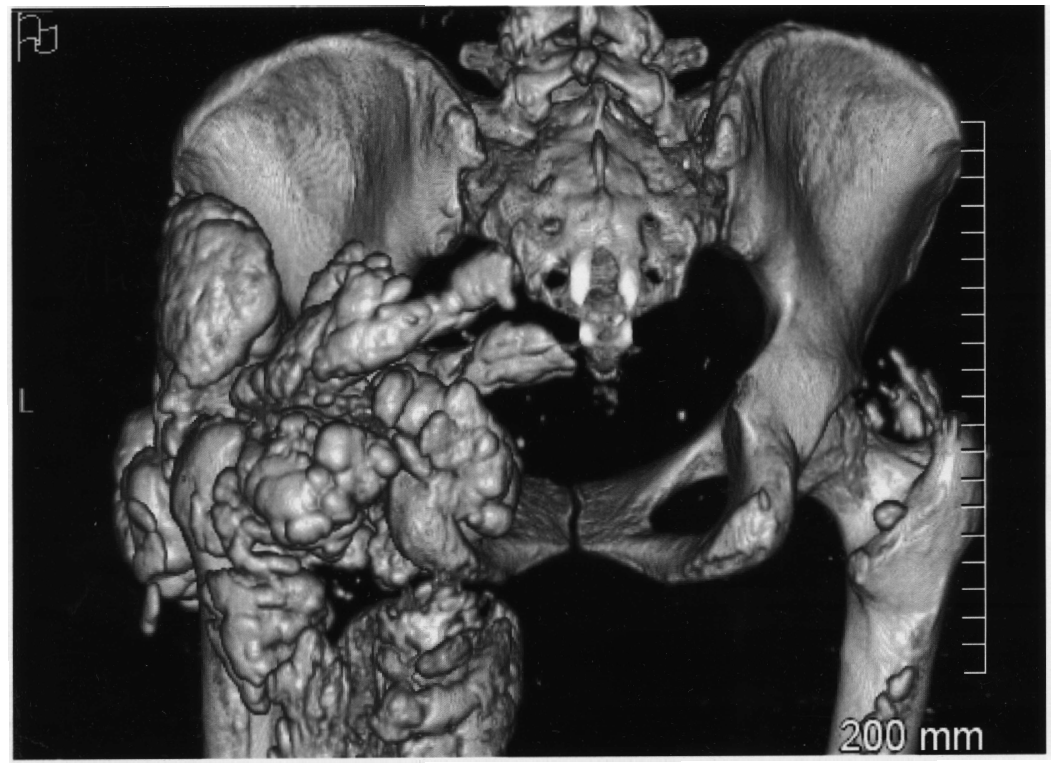

Figure 1. Computed tomography demonstrated tumoral soft tissue calcification surrounding the left hip joint. 